\title{
Managers' attitudes to creativity and innovation practices in the creative industries
}

\author{
Atitudes dos gestores face à criatividade e às práticas de inovação nas indústrias criativas
}

Fernando Cardoso de Sousa

University of the Algarve, CIEO/UAlg - Research Centre for Spatial and Organizational Dynamics; GAIM - Marketing Research Centre; APGICO - Portuguese Association for Creativity and Innovation in Organizations, Portugal, cardoso_sousa@hotmail.com

Florbela Nunes

IEFP - Employment and Professional Training Service, Evora, Portugal, florbela.nunes@iefp.pt

\section{lleana Pardal Monteiro}

University of the Algarve, ESGHT and CIEO - Research Centre for Spatial and Organizational Dynamics; APGICO - Portuguese Association for Creativity and Innovation in Organizations, Portugal, imontei@ualg.pt

\begin{abstract}
This article aims to demonstrate that the relationship between entrepreneurs' attitudes to creativity and business innovation practices is stronger in the case of creative industries. A sample of 454 managers of micro and medium-sized companies (94 belonging to creative industries) was surveyed using an inventory of innovative business practices and the scale of attitudes towards creativity. The results, derived from a linear regression model (two factors for the scale of attitudes - Leadership and Autonomy - and for the inventory of business practices - Performance and Strategy), confirmed the proposition by revealing the influence of the creative attitudes of managers regarding the company's innovative practices, fundamentally on Strategy, especially in the creative industries segment. The innovative manager appeared as a disciplined individual driven to collaborating with the employees. Although this research requires further evidence, the results suggest interesting characterisations of the managers who develop their activity in the cluster of creative industries.
\end{abstract}

Keywords: Creativity, innovation, creative management, creative industries.

\section{Resumo}

Este artigo tem como objetivo demonstrar que a relação entre as atitudes do empresário face à criatividade e as práticas de inovação é mais forte no caso das indústrias criativas. Foram inquiridos 454 gestores de micro, pequenas e médias empresas (94 pertencentes às indústrias criativas), utilizando um inventário de práticas empresariais e uma escala de atitudes face à criatividade. Os resultados, obtidos utilizando um modelo de regressão linear (dois fatores para a escala de atitudes -Liderança e Autonomia - e dois para o inventário de práticas empresariais - Desempenho e Estratégia) confirmaram a hipótese, ao revelar a influência das atitudes do empresário face à criatividade sobre as práticas inovadoras da empresa, nomeadamente na Estratégia e no segmento das indústrias criativas. O gestor inovador surge como um indivíduo disciplinado, orientado para colaborar com os empregados. Apesar desta investigação necessitar de maior aprofundamento, os resultados sugerem uma caracterização interessante dos gestores que desenvolvem a sua atividade no cluster das indústrias criativas.

Palavras-chave: Criatividade, inovação, gestão criativa, industrias criativas.

\section{Introduction}

Following the statements of Coakes and Smith (2007), only innovation can allow a company to continue to optimise the introduction of original products at the right time, in the right market, and with the right distribution network. In turn, Tucker (2008) states that what separates the company from the competition are the ideas, knowledge, commitment and the innovation skills of employees. So, being innovation the general rule in organisations, creativity becomes not only desired but sought, with companies striving to incorporate it into their culture. Thus, the organisational strategies are increasingly focusing on creativity that, in general, is associated with innovation practices (Keogh \& McAdam, 2004). Therefore, creativity supports a corporate culture that encourages innovative expression with a strong entrepreneurship relationship (Drucker, 1985). In turn, the attitudes of entrepreneurs towards creativity influence the type of leadership exercised, and various authors, (e.g. Cummings \& O'Connell, 1978; Howell \& Avolio, 1993; Woodman, Sawyer, \& Griffin, 1993), point to the influence of leadership on organizational innovation, which McAdam and Keogh (2004) found having a positive effect on micro and small enterprises. This influence between leadership and innovation is seen more often in the so-called "creative industries" (Bilton, 2007) because of the collaborative nature of a business activity connected to art and technology.

Consequently, given that in the Portuguese business context one can get examples of such industries, this article aims at demonstrating that the influence of creative attitudes on innovative business practices is evident when considering entrepreneurs running micro-enterprises and SMEs, whose activities fall in what is meant by creative industries. Because of this influence, after describing approaches to creative industries, creativity and innovation, and their insertion in a model closer to this type of industry, the article discusses the attitudes of management in the face of creativity and its role in company innovation. After this presentation, the investigation is described, ending with a discussion of the results and conclusions.

\section{Creative Industries}

The notion of creative industry is associated with economic and social changes that displace the focus of industrial activities to 
those related to knowledge. It emerged in the early 1990s in Australia, assuming greater importance when integrated into the policies defined in the United Kingdom, the DCMS (Department of Culture, Media and Sports).

Linked with the economic growth revitalisation, "creative industries" is a concept that may be different from country to country, turning it almost impossible to make comparisons (Newbigin, 2014). However, it always includes activities in which creativity is incorporated into the core of the business, being simultaneously "art, science and business" (Henry, 2007). This type of industry includes a wide range of activities with a common characteristic: they rely heavily on imagination and individual creativity and, according to Hartley (2005), are associated with skill and talent.

The DCMS believe that the creative industry is the production and distribution circuits of goods and services that use creativity and intellectual capital as raw materials, as focused by Howkins (2001), who connects the creative industries to value attribution to knowledge, work and intellectual property.

The emergence of the knowledge society (Castells, 2000) is oriented to an economy based on the individual and his intellectual resources, together with information and knowledge exchange capacity, in contrast with an economy centred on the intensive use of capital and work and oriented to mass production. In a post-materialistic society, the interests no longer revolve around the satisfaction of basic needs but around the aesthetic, intellectual, life quality and participation needs, carried out with autonomy.

This change is associated with a discourse about the change in values, disruptions and innovation (Howkins, 2001). In fact, the current trend focuses on the individual and reflects changes in terms of values, personal preferences, lifestyles and consumption patterns, different and apart from traditional behaviours. The change that puts creativity and innovation as a central element of the organisations is an individual and collective one, being critical to the organisations' development, performance and competitiveness (Mumford, 2012). Similarly, Howkins (2001) associates the creative industries to the "imperatives" of originality, with a focus on creativity and innovation, and presenting ways of turning ideas into money.

The year 2008 also represents a milestone, when UNESCO (United Nations Educational, Scientific and Cultural Organisation) (UNESCO, 2008) established the creative economy as a way to boost economic growth, representing an alternative for development, especially for being based on creativity and able to use cultural and social characteristics of each country/region as an advantage for the development and production of unique and competitive goods and services.

In general terms, the benefits of the creative economy can be found in four levels: (a) job creation, exportation, social inclusion and cultural diversity; (b) intertwining of economy, culture and social aspects with technology, intellectual property and tourism objectives; (c) economic system based on knowledge, developing links between elements of macro and micro economy; and (d) development of innovation through multidisciplinary policies. At the same time, support policies by governments become important to support creative businesses, which have grown over time.

Creative cities are a central part of the movement of global trade on the creative economy, thus creating a network of cooperation and talents worldwide. The emergence and strengthening of these kinds of cities transform the environment where they are located and enhance dynamism into the sectors involved (Landry, 2003).

We are witnessing then an integrated and consistent vision which calls for the growing importance of the creative economy and affirms its value and benefits for growth and socioeconomic development (Caves, 2001; Bendassolli, Wood Jr., Kirschbaum \& Cunha, 2009; UNESCO, 2010; DCMS, 2012; Florida, 2014). This highlights four components considered inseparable from the disruptive nature of the creative industries:

- Creativity is the central element necessary and essential for production.

- Coupled with different resources management, the convergence between arts, business and technology is cultivated.

- The generation of innovative content can be translated into salable products.

- The economic value is based on the cultural and intellectual property.

This phenomenon can generate and trade ideas with "significant value", which Throsby (2004) identifies with a set of dimensions:

- Aesthetic - reflects beauty, harmony and form.

- Spiritual - seeks spiritual meaning shared by all human beings, including understanding, insight and awareness.

- Social - creates links between individuals, fostering an environment in which the relationships and identities can thrive.

- History - ensures clarity and a sense of continuity with the present.

- Symbolic - gives meaning and symbolic value, which will be broadcast by work to the consumer.

- Authenticity - stresses the fact that a work of art represents reality is original and unique.

Indeed, the creative industries represent the economic areas that, in the early years of the twenty-first century, have assumed greater importance, giving place to the growth of central sectors to success and economic development (Fleming, 2008; Henry, 2007). Taking the UK as an example, the creative industries can help transform some cities, as it is the case of 
Manchester and Glasgow, being London a case of higher economic and social weight. In Britain, in 2007, these industries involved two million jobs and contributed, in 2009, with $2.9 \%$ of wealth for the British economy (DCMS, 2012).

In Portugal, the dissemination and promotion of the creative economy is a strategic objective and, in accordance with paragraph 8 of the Technological Plan Coordination Unit (2005), sectors included in the creative industry concept are: advertising, architecture, art and antiques market, design, fashion, audiovisual productions, educational software and leisure, music, performing arts and entertainment, broadcast through television, radio and internet, writing and publishing, and can include other economic activities involving cuttingedge technologies, such as research in life sciences or engineering. The cultural heritage, tourism and museums are also identified as being close to the creative industries.

The macroeconomic study of Mateus (2010), on the development of a cluster of creative industries, linking innovation to the creative industries and their concentration, responds to the challenge of mapping a region. At the same time, it is also an example of the opportunity to propose a new development paradigm that joins culture and economy, recognizing that creativity, knowledge, innovation and access to information are the engines of development in the global world.

In view of the foregoing, this new business area, based on innovation, intuition, creativity, and new products and services launch, is gaining space and growing importance in the globalised world. In this scenario, the development of information and communication technologies must be enhanced as it is essential in spreading new ways of producing innovative products. This side of the economy, which turns creativity into capital, requires that companies have an ongoing responsibility within training and updating so that innovation in products and processes is present.

\section{Creativity and innovation}

As Woodman and Schoenfeld (1990) recall, the term creativity can be seen either as a social concept, expressed by people's implicit theories or as a theoretical construct, developed by researchers in the field. Considering the theoretical definitions, and after carefully analysing the propositions evidenced by Kasof (1995), it is possible to conclude that the construction of creativity was (and still is) used in scientific literature to designate something perceived by others. Stein (1953) maintains that creativity is a process that results in novelty, which is accepted as useful, tenable, or satisfying by a significant group of others at some point in time. Amabile (1983) mentions that a product or response is creative to the extent that appropriate observers independently agree it is creative and can also be regarded as the process by which something so judged is produced. These examples illustrate what may be designated as hetero-attributed creativity, something pertaining to the communication process.
As the product of that communication process, creativity appears connected to what is perceived as new by someone other than its originator, or as the putting to use of an idea (Kanter, 1983; West \& Farr, 1990), in the domains of production, adoption, implementation, diffusion, or commercialisation of creations (Rogers, 1983; Spence, 1994). In these cases, creativity is seen as innovation.

Creativity seems then to acquire its full meaning as a process of communication between the creator (or the product) and the judges or audience (hetero-attributed), or between the creator and the product (self-attributed). Innovation seems to be more appropriate to designate the resulting attribution made by the audience apropos the product. As a consequence, heteroattributed creativity can only be measured through sociocultural judgements, being, therefore, context-dependent. As mentioned by Csikszentmihalyi (1991), creativity is located in neither the creator nor the creative product but rather in the interaction between the creator and the field's gatekeepers who selectively retain or rejects original products.

Regarding innovation, Ghoshal and Bartlett (1987) classify it into broadly two categories: those that see innovation as the final product - the idea, practice, or material artefact that has been invented or that is regarded as novel independent of its adoption or non-adoption - and those who see it as a process, which proceeds from the conceptualisation of a new idea to a solution of the problem and then to the actual utilisation of a new item of economic or social value. However, this distinction between creativity (undoubtedly the source of the whole process) and innovation is a minor issue in the corporate context, since the most important question turns out to be with regards to the system that allows putting the ideas into practice. Therefore, for every creative act producing an idea or a product, a social act is required to promote it in the organisation and that is the reason why real innovation in companies is always a team effort (Woodman, Sawyer, \& Griffin, 1993). Every innovation starts with an initial idea but needs a system to expand the individual creativity and install it at the group level. This group will need to solve a wide variety of problems resulting from the adoption, dissemination and implementation of the product.

As Burns and Stalker (1996) explained, if innovation does not necessarily need creativity to emerge, for it can be reached by introducing new techniques or technologies, it cannot be ignored during the adaptation process required to succeed in the market. Innovation for the sake of innovation can even be harmful to the enterprise, as happened when Coca-Cola tried a different flavour, or it could happen if McDonald's changed its production chain.

Individual creativity seems always to be the starting point because it may exist even in the absence of innovation. As to innovation (Kilbourne \& Woodman, 1999), it depends on a vast number of variables besides creativity, such as autonomy, the available information, the reward system, education and 
training, the system of authority, participation in decisionmaking, or the team cohesion.

\section{Attitudes and Creative Management}

The construct of "attitude" was formulated by Allport (1935) to designate a mental and neural state of readiness, organized through experience, exerting a directive and dynamic influence upon the individual's response to all objects and situations with which it is related, activating affective, cognitive and behavioral processes (p. 810). Some researchers noted that these three parts are deeply intertwined, thus preferring to adopt a single dimension, defining attitude as a summary evaluation of an object of thought (Vogel \& Wänke, 2016, p. 2). In the present work, we would rather adopt the latter definition, speaking of attitudes as an evaluation towards a presented social object in this case, creativity.

The discussion considers whether such evaluations must be stable and consistent over time, retrieved from long term memory, following the "file-drawer model" (Wilson \& Hodges, 1990), or if they rely on temporary or recent information, as in the "attitude as construction perspective", in such a way that context is likely to influence an individual's attitudes. Allport's (1935) seminal work has established attitude formation as a process of organisation and sense-making of experiences, thus influencing individual behaviour. Following the author's work, we may state that information towards present or past behaviour may determine the construction of an attitude.

In the organisational context, Basadur and Basadur (2012) explain that attitudes towards creativity play a function of adaptation to the environment and may relate to the search of original and valuable strategies of reality interpretation, which promote innovative practices. Management plays a fundamental role in analysing the context, identifying problems and searching for corresponding solutions in a way that builds a creative attitude. In addition, Goodman (1995) used the term of management's creative response to refer to the way managers give structure to the organisational context, manage team's autonomy in project development, and use participatory processes. In addition, Gomes, Rodrigues, and Veloso (2015) show the importance of managers' role in bundling the contextual factors that help create a system in which creativity and innovation become embedded in the organisational culture.

A Manager's creative attitude is strongly related to the search for opportunities and differentiated experiences (Florida, 2014), as creativity is the result of hard work and profound knowledge in the domain one is working in. The research focused on creative industries, and the management of creative people showed some tensions and paradoxes, as did the need for freedom and total devotion to the art, together with the need to manage the business in very organised terms (Eikhof \& Haunschild, 2006). These tensions also emerged in Armstrong and Page's (2015) research, aiming at identifying leadership and management of creative people in the United Kingdom's creative industries, showing five significant tensions of the creative leader. Firstly, the tension between commercial constraints - centred on the effort to commercialise the products and on restrictions to experimentation - and creative freedom - focused on the creation and experimentation requiring few restrictions. Secondly, management roles fear failure and do not appreciate new experiences, preferring to stick to the tried and tested, versus the appetite for risk, which drives the creative leader to try new solutions, new products and develop new talents. A third tension refers to competition opposed to collaboration - a competition which imposes secrecy to protect the ideas, the intellectual property keeping business under control and collaboration indispensable to creativity, helping to develop new ideas and maintain openness to others and new opportunities. A fourth tension deals with automation, granting faster results and cost reduction, versus craft skills, which uses technology to develop creative processes. Finally, time horizon; long-term, dealing with strategy, people management and talent development, and short-term, experimenting, improving and project management. The leaders in Armstrong and Page's (2015) research highlight the importance of mentors or role models, helping them to develop the attitudes suitable to creative industries and creative people.

These considerations allow us to establish the proposition stating that managers' attitude towards creativity and managerial innovation practices is stronger in the creative industry sector, as we try to demonstrate in the following section.

\section{Method}

To study the research question, a multiple linear regression analysis, with a stepwise selection of variables, was used to obtain a parsimonious model that allowed to make predictions about the dependent variables.

\subsection{Sample}

The study was carried out using an opportunity sample consisting of 454 individuals, responsible for micro and SMEs in Portugal. Managers in the sample were predominantly male, representing $71 \%$ of respondents. Aged between 23 and 84 years (mean 44 ), the majority (59\%) had higher qualifications, and more than $25 \%$ had completed secondary education. About half $(42 \%)$ of the subjects had an entrepreneurial experience higher than ten years, and the vast majority (84\%) had previous professional experience (average six years).

In the study, micro and small companies were predominant: $61 \%$ had fewer than ten employees and $33 \%$ between 10 and 49; only the remaining $6 \%$ were medium-sized enterprises, hiring more than 50 people. These companies were headquartered mainly in the North and Centre (30\% and $29 \%$, respectively), from Lisbon and Tagus Valley (11\%), while the South had the remaining $30 \%$. 
Considering the sectors included in the concept of "creative industry", a segment composed of 94 managers was selected. This segment was responsible for companies with consulting activities, media and advertising, social support services and education, crafts, art, recreation and leisure. It represented $21 \%$ of the sample described, being similar in terms of gender, previous experience, size, and geographical distribution, concerning the total sample. Managers of this segment constituted, however, a younger group, with a mean age of 41 years and with a lower level of education, where only $38 \%$ had a grade school of higher education and about half $(53 \%)$ had completed secondary education. The business experience was also lower, as only about a third (34\%) had been a manager for over ten years.

\subsection{Instrument}

The data collection was carried out with questionnaires consisting of an inventory and a scale. The inventory was intended to identify innovative business practices and, in its preparation, the structure and application form contents of the SME Innovation Network COTEC Portugal were considered. The general objectives of COTEC's inventory were to promote public recognition of a group of SMEs by their attitude and innovative activity. This form was adapted to our target population and resulted in an instrument addressing four themes, or dimensions, of cross-business innovation:

1. Conditions: involving the strategic aspects susceptible to influence entrepreneurial attitudes and behaviours towards innovation, which include culture, leadership and business strategy.

2. Resources: refers to the contribution of different types of organisational resources to ensure more dynamic and better innovation performance, involving human capital, skills and foreign relations.

3. Processes: concerns the most relevant organisational processes for innovative dynamics of the organisation, and its performance in terms of innovation, involving the management of IDI activities, learning and results.

4. Results: ascertains to what extent conditions, resources and process-oriented innovation translate themselves into results. This involves the financial and operational aspects, the market and society.

The inventory of innovative business practices consisted of a total of 20 binary or dichotomous (yes/no) questions. The collection of items took into account the objectives of the original instrument and what was intended with its adaptation, which aimed to verify the existence of certain behaviours, assigning a code for the expression of a given characteristic and, the other, the absence of that feature.

This instrument was submitted to the validation of COTEC Portugal, where the person in charge of the SME Innovation Network, responded positively to the adjustments made, having suggested changes in its use. The association was also informed that the inventory would be used along with the scale.
The scale was designed to identify creative attitudes by selfperception. Its development started from the Creative Investment Theory, from Sternberg and Lubart (1991; 1996), which refers to the confluence of different sources of investment in creativity that interact with each other, consisting of six dimensions that describe:

1. Intelligence: points out the theoretical and practical ability to redefine problems, analyse and recognise good ideas and persuade the value of one's ideas. It involves synthetic capabilities, analytical and practical-contextual.

2. Cognitive styles: relates to the way of thinking and how the person exploits and uses intelligence. It involves the legislative styles, executive and judicial.

3. Knowledge: concerns formal and informal knowledge acquired by books and the like, and by dedication, respectively.

4. Personality: involves the set of features that characterise the individual. It involves aspects such as the willingness to take risks, trust in yourself, tolerance for ambiguity, the courage to express new ideas, perseverance and selfesteem.

5. Motivation: refers to the driving force of the creative performance. An oriented task determines the passion, concentration and energy at work.

6. Environmental context: refers to the environment in interaction with the individual, which facilitates creative expression. It involves aspects such as family, school, organisations and society, contributing, directly or indirectly, to creative expression.

The scale consisted of 36 questions, and the answer to the items was carried out using a four-point Likert-type matrix expressed in terms of the agreement: 1- strongly disagree; 2 disagree; 3 - agree, and 4 - totally agree. We adopted this fourpoint scale to reduce central tendency bias. The items were written in the positive, for the sake of clarity and simplicity, across the six dimensions, with a total of nine items for each dimension.

Confirmation of the metric characteristics of the instruments was ensured by a pilot study with 180 entrepreneurs who subsequently joined the sample. The descriptive analysis of the results of responses to the instruments showed a normal distribution, mean, standard deviation, minimum and maximum for each item.

In order to identify a smaller number of variables, by reducing the complexity of the analysis, we chose the factor analysis of the instruments, using the extraction of the principal components with varimax rotation. The inventory of business practices, after eliminating 10 items, resulted in two factors, explaining $48 \%$ of the variance, with Factor 1 - Performance (prestige and image, development of the business sector and the creation of skilled employment) with an alpha coefficient Cronbach's 0.75, and Factor 2 - Strategy (employee 
participation, goal setting, human resources management, activities), with a coefficient of 0.67 . The composition of each external cooperation and management, and evaluation of

factor is shown in Table 1.

Table 1 - Saturations of each item of inventory of innovative business practices, after varimax rotation, and respective percentage of explained variance

\begin{tabular}{|c|c|c|}
\hline \multirow{2}{*}{ Items } & \multicolumn{2}{|c|}{ Factors (\% explained variance) } \\
\hline & $\begin{array}{c}\text { Performance } \\
(26 \%)\end{array}$ & $\begin{array}{c}\text { Strategy } \\
(22 \%)\end{array}$ \\
\hline The innovation activities have a positive contribution to financial performance. & .68 & .07 \\
\hline The human capital has a positive contribution to financial performance. & .61 & .15 \\
\hline The innovation activity contributes to prestige and good image. & .84 & .15 \\
\hline The innovation activity has a positive impact in terms of skilled job creation. & .56 & .12 \\
\hline It has a clear and shared innovation strategy, involving workers in its definition. & .19 & .66 \\
\hline It has an innovation strategy translated into an action plan with medium and long term goals. & .09 & .72 \\
\hline It has a human resource management policy geared to innovation. & .06 & .51 \\
\hline Develops systematic cooperation actions in innovation with external entities & .05 & .60 \\
\hline
\end{tabular}

As shown in Table 2, from the range of creative attitudes resulted factors with a Cronbach's alpha of 0.85 , for factor 1 , and $\mathbf{0 . 7 9}$, for factor 2, obtained after deleting 11 items. The study of dimensionality allowed the definition of two factors with eigenvalues greater than 1 , which explained $48 \%$ of the variance:
- Leadership - defined by imaginative capacity, capacity assessment, exposure, fluidity, mobilisation of the other, valuing the other, humility, flexibility, adaptability, security and persistence.

- Autonomy - defined by organisational skills, self-assessment, dedication to work, objectivity and ability to concentrate.

Table 2 - Saturations of each item of the scale of attitudes towards creativity, after varimax rotation, and respective percentage of explained variance

\begin{tabular}{|l|c|c|}
\hline \multicolumn{1}{|c|}{ Items } & \multicolumn{2}{|c|}{ Factors (\% explained variance) } \\
\hline & $\begin{array}{c}\text { Leadership } \\
(\mathbf{2 9 \% )}\end{array}$ & $\begin{array}{c}\text { Autonomy } \\
\mathbf{1 0 \% )}\end{array}$ \\
\hline I seek new solutions to respond to old problems. & .57 & .08 \\
\hline I easily identify good ideas or projects. & .56 & .18 \\
\hline I easily expose ideas and projects. & .51 & .35 \\
\hline I mobilise others to follow my ideas. & .64 & .03 \\
\hline I value the skills of my staff. & .63 & .14 \\
\hline I share the ideas that you learn every day. & .63 & .09 \\
\hline If necessary, I change my routines. & .70 & .13 \\
\hline I adapt myself easily to new environments. & .75 & .08 \\
\hline I am able to express my ideas, even in unfavourable circumstances. & .63 & .30 \\
\hline Usually, I don't give up in the face of difficulties. & .65 & .26 \\
\hline I organise my day-to-day clearly. & .01 & .79 \\
\hline I set goals to improve my performance. & .17 & .75 \\
\hline I dedicate myself to work with method and rigour. & .05 & .79 \\
\hline I seek to implement clear projects. & .38 & .63 \\
\hline I concentrate easily on the tasks ahead. & .42 & .54 \\
\hline
\end{tabular}

This resulted in two instruments, with two factors each, but with different scales (dichotomous, for innovation practices, and a four-point, to attitudes towards creativity), and with few effects of collinearity (significant regression coefficients and correlations between factors of different instruments with less than 0.2), which, along with the internal consistency of the factors, came in support of its validity.

\subsection{Procedure}

As mentioned above, the data collection was carried out with a questionnaire consisting of two parts: an inventory of innovative business practices and a scale of creative attitudes.
About 3.250 Portuguese companies - Micro and SME - based in Portugal, were contacted, regardless of the industry. This process resulted in 454 valid responses (14\% of the target population), obtained electronically. As to ethical considerations, the first concern was with the establishment of an agreement with the organisations involved in this research so that no one would be identified.

\section{Results}

Considering the research proposition of this investigation (managers' attitudes towards creativity and managerial innovation practices is stronger in the creative industry sector), 
we aimed to answer it by means of a multiple linear regression, having the dependent variables of the business practices (Performance and Strategy factors) as a function of the independent variable creative attitudes (Leadership and Autonomy factors). The results generally showed the influence of creative attitudes on innovative business practices, verifying that managers' leadership and autonomy influenced their strategy and performance. As indicated in Table 3, and taking Performance as the dependent variable, the model explained a significant variance percentage (3\%), where Leadership is responsible for this variability, having Autonomy been deleted. Taking Strategy as a dependent variable, it was found that the explained variance increased (7\%) due to the Autonomy factor, but still with both factors identified as predictors.

Table 3 - Values of explained variance (R2), regression coefficient (B), and respective significance of the variables "Autonomy" and "Leadership", in each of the factors of "Innovation Practices" ( $N=454)$

\begin{tabular}{|c|c|c|c|}
\hline \multicolumn{2}{|c|}{ Factors (Creative Attitudes) } & \multicolumn{2}{|c|}{ Factors (Innovation Practices) } \\
\hline & $\mathrm{R}^{2}$ & Performance & Strategy \\
\hline Leadership & $\beta$ & $.03\left(^{* *}\right)$ & $.07\left(^{* *}\right)$ \\
\hline Autonomy & $\beta$ & $.13\left(^{* *}\right)$ & $.12\left(^{*}\right)$ \\
\hline
\end{tabular}

$\left({ }^{* *}\right)$ Significant to $p<.01 ;(*)$ Significant to $p<.05$

It was observed that the attitude towards Leadership influenced the performance indexes and the attitude towards Autonomy (the Strategy indexes). Finally, until what extent the segment of creative industries differed in the linear regression was examined, with the results shown in Table 4 . In the analysis of this group - 94 managers - the relationship was strengthened, in particular, the attitudes towards creativity and Strategy, responsible for $14 \%$ of the variance, which placed the perception of Autonomy as a key predictor of Strategy. Also, with higher intensity than in the global sample $(5 \%$ of the explained variance), the perception of Leadership as a predictor of Performance.

Table 4 - Values of explained variance (R2), regression coefficient (6), and respective significance of the variables "Autonomy" and "Leadership", in each of the factors of "Innovation Practices", for Creative Industries (N=94)

\begin{tabular}{|c|c|c|c|}
\hline \multicolumn{2}{|c|}{ Factors (Creative Attitudes) } & \multicolumn{2}{|c|}{ Factors (Innovation Practices) } \\
\hline & $\mathrm{R}^{2}$ & Performance & Strategy \\
\hline Leadership & $\beta$ & $.05\left(^{*}\right)$ & $.14\left(^{* *}\right)$ \\
\hline Autonomy & $\beta$ & $.25\left(^{*}\right)$ & .19 \\
\hline
\end{tabular}

$\left.{ }^{* *}\right)$ Significant to $\mathrm{p}<.01 ;(*)$ Significant to $\mathrm{p}<.05$

Thus, $35 \%$ of the managers who were part of the sample, allowed the execution of a significant linear regression model, and the relationship of the influence between the variables was more significant compared with the initial regression model.

In addition, it should be noted that the variables of personal development and context, and the gender, age and education, did not show statistical significance, by contrast with previous experience, business concentration and the business sector of creative industries.

It was concluded that there was a set of mediators that related creativity and innovation, operating at a multilevel (individual, team and organisational), influenced by individual character variables and organisational context.

\section{Discussion}

The main results of this investigation came from a linear regression model that revealed the existence of an influential relationship between the variables under study and the attitudes towards creativity and innovation practices in the business context. This relationship was based on the specificity of the influence of the creative attitudes of managers on the company's innovative practices, fundamentally on the strategy. The segment of the creative industries has shown an increased variance, as compared to the initial sample, indicating a dependency between innovative business practices and creative attitudes in an environment conditioned by the context of a particular type of activity.

Thus, it is possible to conclude that the breakthrough capacity is influenced by a number of characteristics (e.g. intelligence, personality or motivation), wherein the medium in which it operates, and with which it interacts, also influences innovative orientation. Working in the creative medium seems to favour and stimulate active and creative attitudes and, consequently, the implementation of relevant practices in terms of business innovation. Leadership is assumed as one of the factors that affect innovation, in a line of thought also advocated by Mumford (2012), which refers to the importance of leadership in motivating employees to foster innovation. Indeed, 
leadership is stated as a determinant of innovation, being the creative leader responsible for business impact and performance (Cummings \& O'Connell, 1978; Woodman, Sawyer \& Griffin, 1993), along with a leading role of creating and maintaining a favorable climate for the creation and sharing of ideas (Robinson, 2001).

Attitudes were worthy of special interest, in face of the importance of the organisation and the dedication to work, objectivity and ability to concentrate on practices that result in employee participation, goal setting, human resources management, external cooperation and evaluation activities. There seems to be a real sense of discipline, delivery and humility that determines much of the collaborative attitude in company management. If this seems to be more a marked feature in creative industries, it may be due, not only to the more significant skills and expertise of the employees but to the need for greater perseverance and delivery to obtain favourable results in line with what was already identified by Eikhof and Haunschild (2006). The idea that transpires here is that the innovative manager is, above all, a disciplined individual, driven to share decisions with employees. Discipline, persistence and collaboration arise here as the keywords of innovation in companies, especially in the creative industries.

As to the limitations of this study, we found that although the instruments used have revealed good metric qualities, regarding the explanatory power of the items and their grouping factors, consistency was not very significant (Cronbach's alpha was less than 0.70 in the case of Factor 2, Strategy). Another limitation had to do with the fact that the sample was one of opportunity, not enabling to generalise results to similar groups. Finally, it should be noted that the studies mentioned, although related to the theme that we tried to develop, giving it sustainability and heuristic value, hinder comparative analysis and systematisation of knowledge related to the creative industries.

Given the conclusions and the limitations presented, and considering the emerging predictive model, we suggest further research to explain how more and better teachings may be withdrawn from creative industries, and how they can take advantage of their employees' creativity. The link between innovation and the observation of a strict work discipline is also of research value.

\section{References}

Allport, G. (1935). Attitudes. In C. Murchison (ed.). Handbook of social psychology. (pp. 798-844). Worcester Mass: Clark University Press.

Amabile, T. (1983). The social psychology of creativity. New York: Springer-Verlag.

Armstrong, A. \& Page, N. (2015). Creativity and constraint: Leadership and management in the UK creative industries. Hertfordshire: Ashridge Business School.

Basadur, M.S., \& Basadur, T. (2012). Attitudes and creativity. In M. Runko \& S. Pritzker (eds.), Encyclopedia of Creativity (2nd Ed.). New York: Elsevier.
Bendassolli, P.F., Wood Jr, T., Kirschbaum, C. \& Cunha, M.P (2009). Industrias criativas: Definição, limites e possibilidades. Retrieved 31 July, 2018, from: http://www.scielo.br/pdf/rae/v49n1/v49n1a03.pdf.

Bilton, C. (2007). Management and creativity: From creative industries to creative management. Oxford: Blackwell Publishing.

Burns, T. \& Stalker, G. (1996). The management of innovation. New York: Oxford University Press.

Castells, M. (2002). A Era da Informação: Economia, sociedade e cultura (Vol. 1). Lisboa: Fundação Calouste Gulbenkian.

Caves, R. (2001). Creative Industries: Contracts between art and commerce. Cambridge: Harvard University Press.

Coakes, E. \& Smith, P. (2007). Developing communities of innovation by identifying innovation champions. The International Journal of Knowledge and Organizational Learning Management, 14(1), 74-85.

Csikszentmihalyi, M. (1991). Society, culture and person: a systems view of creativity. In R. J. Sternberg (ed.). The nature of creativity: Contemporary psychological perspectives (pp. 325-340). Cambridge, NY: Cambridge University Press.

Cummings, L.L. \& O'Connell, M.J. (1978). Organizational innovation. Journal of Business Research, 6, 33-50.

DCMS (2012). Creative industries' facts and figures. Retrieved 23 August, 2018, from http://www.culture.gov.uk/what_we_do/creative_industries/default. aspx.

Drucker, P. (1985). Innovation and entrepreneurship: Practice and principles. New York: Harper e Row.

Eikhof, D. R. \& Haunschild, A. (2006). Lifestyle Meets Market: Bohemian Entrepreneurs in Creative Industries. Creativity and Innovation Management, 15(3), 234-241.

Fleming, T. (ed.) (2008). Estudo macroeconómico: Desenvolvimento de um cluster de indústrias criativas na região norte. Porto: Fundação de Serralves.

Florida, R. (2014). The rise of the creative class - Revisited. New York: Basic Books.

Goodman, M. (1995). Creative management. New York: Prentice Hall.

Gomes, J., Rodrigues, F. \& Veloso, A. (2015). Creativity at work: The role of context. In H. Shipton, P. Budhwar, P. Sparrow, P. \& A. Brown (eds.), Human Resource Management, Innovation and Performance (pp. 282297). London: Palgrave Macmillan.

Hartley, J. (2005). Creative Industries. London: Blackwell.

Henry, C. (2007). Entrepreneurship in the creative industries: An international perspective. Cheltenham: Edward Elgar, Ltd.

Howell, J.M., \& Avolio, B.J. (1993). Transformational leadership, transactional leadership, locus of control and support for innovation: Key predictors of consolidated business unit performance. Journal of Applied Psychology, 78, 891-902.

Howkins, J. (2001). The creative economy: How people make money from ideas. London: Allen Lane.

Kanter, R. (1983). The change masters. New York: Simon \& Schuster.

Kasof, J. (1995). Explaining creativity: The attributional perspective. Creativity Research Journal, 8, 311-365.

Kilbourne, L. M., \& Woodman, R. W. (1999). Barriers to organizational creativity. In R. E. Purser \& A. Montuori (eds.), Social creativity (Vol. 2, pp. 125-150). Cresskill, NJ: Hampton Press, Inc.

Landry, C. (2003). The creative city: A toolkit for urban innovators. London: Penguin Press.

Mateus, A. (2010). Sector cultural e criativo em Portugal. Lisboa: Ministério da Cultura.

McAdam, R. \& Keogh, W. (2004). Transitioning towards creativity and innovation measurement in SMEs. Creativity and Innovation Management, 13(2), 126-139.

Mumford, M. (ed.) (2012). Handbook of organizational creativity. USA: Academic Press. 
Newbigin, J. (2014). What is the creative economy? The British Council. Retrieved 1 August 2018, from https://creativeconomy.britishcouncil.org/guide/what-creative-

economy/.

Robinson, K. (2001). Out of our minds: Learning to be creative. UK: Capstone Publishing, Ltd.

Rogers, E. M. (1983). Diffusion of innovations (3rd Ed.) New York: The Free Press.

Spence, W. R. (1994). Innovation: The communication of change in ideas, practices and products. London: Chapman e Hall.

Stein, M. I. (1953). Creativity and culture. The journal of psychology, 36, 311-322.

Sternberg, R. J., \& Lubart, T. (1996). Investing in creativity. American Psychologist, 51, 677-688.

Throsby, D. (2004). Economics and culture. Cambridge University.

Tucker, R. B. (2008). Driving growth through innovation. San FranciscoBerret-Khoeler Publishers.

UNESCO (2008). Creative economy: Report 2008. New York: United Nations.

UNESCO (2010). Creative economy: Report 2010. New York: United Nations.

Vogel, T. \& Wänke, M. (2016). Attitudes and attitude change. London: Routledge Taylor \& Francis Group.

Wilson, T. D. \& Hodges, S. D. (1992) Attitudes as temporary constructions. In L.L. Martin \& A. Tesser (eds.). The construction of social judgements (pp. 37-65). Hillsdale, N.J.: Erlbaum.

West, M. A. \& Farr, J. L. (1990). Innovation at work. In M. A. West \& J.L. Farr (Eds.), Innovation and creativity at work: Psychological and organizational strategies (pp. 3-15). Chichester: Wiley \& Sons.

Wilson, T. D. \& Hodges, S. D. (1992) Attitudes as temporary constructions. In L.L. Martin \& A. Tesser (Eds.), The construction of social judgements (pp. 37-65). Hillsdale, N.J.: Erlbaum.

Woodman, R. W., \& Schoenfeldt, T. (1989). Individual differences in creativity: An interactionist perspective. In Glover, J. A.,. Ronning, R. R \& Reynolds, C. R.(eds.). Handbook of Creativity (pp. 77-93). New York: Plenum Press.

Woodman, R. W., Sawyer, J. E., \& Griffin, R. W. (1993). Toward a theory of organizational creativity. Academy of Management Review, 18(2), 293-321.

Received: 14 August 2018

Revisions required: 22 December 2018

Accepted: 15 February 2019 